\title{
Cotton bacterial endotoxin assessed by electron microscopy
}

\author{
I HELANDER AND K LOUNATMAA \\ From the Departments of General Microbiology and Electron Microscopy, University of Helsinki, Helsinki, \\ Finland
}

\begin{abstract}
A piece of bale cotton was incubated in nutrient broth. Electron microscopic inspection of the cotton and the broth showed Gram-negative bacteria with long flagella, loosely attached to the cotton fibres. Large amounts of endotoxin liberating from these bacteria were visible in the growth medium.
\end{abstract}

The cotton plant and industrial cotton contain a bacterial flora, most of which is comprised of Gramnegative bacteria. ${ }^{1}$ Quantitatively, the greatest contaminant is Enterobacter agglomerans, which constitutes $40-100 \%$ of all Gram-negatives found on cotton, accompanied by Klebsiella, Agrobacterium, and strains of Pseudomonas. ${ }^{12}$

The Gram-negative bacteria contain and excrete ${ }^{3}$ toxic macromolecules, which are lipopolysaccharides (LPS) derived from the outer membrane of the bacteria. ${ }^{4}$ The lipopolysaccharides are composed of a lipophilic moiety (lipid A) and a hydrophilic polysaccharide chain. The lipid $A$ is associated with the endotoxic activities of the lipopolysaccharide molecule, and the polysaccharide part determines the serological specificity of the molecule. These important properties of endotoxins are well documented and have recently been reviewed by Bradley ${ }^{4}$ and Galanos et al. $^{5}$

Although the presence of endotoxins in cotton and its dust has been documented using biological nethods such as the Limulus assay or the Schwartzmann reaction, ${ }^{6}$ there is so far no direct electron microscopic observation about the endotoxins of bacteria on cotton. In this report we describe the shape and the size of some Gram-negative cotton bacteria and their endotoxins and the attachment of the bacteria to the cotton fibre, as shown by two electron microscopic techniques.

\section{Methods}

A $100-\mathrm{mg}$ piece of bale cotton was incubated in Luria-broth (1\% Difco-tryptone, $0.5 \%$ Difco-yeast

Received 24 November 1980

Accepted 22 December 1980 extract, $1 \% \mathrm{NCcl}, 0.025 \% \mathrm{CaCl}_{2}, \mathrm{pH} 7.0$ ) at room temperature. The Luria-broth was changed twice on every second day before the samples were taken for the electron microscopy.

The bacterial suspension in the growth medium was negatively stained on the grid with a $1 \%$ solution of potassium phosphotungstate, $\mathrm{pH} 7 \cdot \mathbf{0}$. The samples for thin sectioning were pre-fixed with $3 \%$ glutaraldehyde in $0.1 \mathrm{M}$ phosphate buffer, $\mathrm{pH}$ $7 \cdot 2$; ruthenium red was added to the final concentration of $1500 \mathrm{ppm}$. After the 45 -minute pre-fixation the samples were post-fixed in $0.1 \mathrm{M}$ phosphate buffer with $1 \%$ osmium tetroxide for two hours at room temperature. After dehydration in a rising ethanol series the samples were embedded in Epon 812. Thin sections were prepared with an LKB Ultramicrotome I and were post-stained with uranyl acetate and lead citrate. For scanning electron microscopy the samples were pre-fixed as above and then dehydrated by the critical-point method $^{7}$ in an Aminco apparatus before the sputtering coating with gold in a JEOL ion sputter JFC-1100. The micrographs were taken with a JEM-100B electron microscope and with a JSM-35C scanning electron microscope operating at 80 and 11 $\mathrm{kV}$, respectively.

\section{Results}

The bacteria that grew in the Luria-broth were found to be Gram-negative with some long flagella (fig 1). The peeling of the outer membrane (arrowhead in fig 1) is seen in this negatively stained preparation. Bacteria were seen growing on the cotton fibres (fig 2) and free endotoxin was observed in the growth medium, as shown in the micrograph of thinsectioned material from the medium (fig 3). This 394 


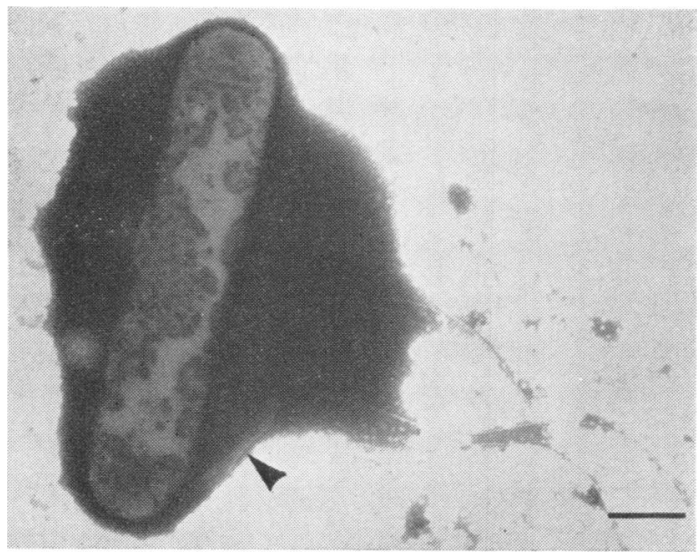

Fig 1 A negatively stained cotton bacterium with long flagella. Peeling of the outer membrane is shown by the arrowhead. Bar, $0.5 \mu \mathrm{m}$.

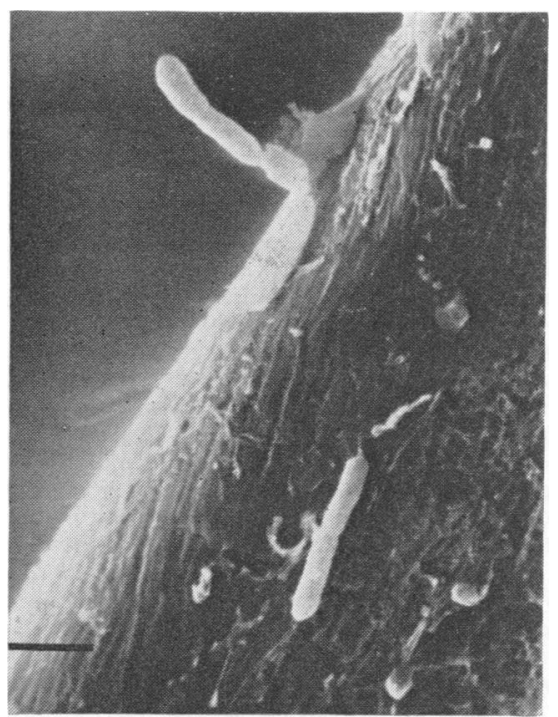

Fig 2 Scanning electron micrograph showing bacterla attached to surface of cotton fibre. Bar, $2 \mu \mathrm{m}$. endotoxin (arrowheads in fig 3) with a unit membrane structure is about $10 \mathrm{~nm}$ in diameter. This agrees very well with the dimensions of the outer membrane of Gram-negative bacteria. The endotoxin vesicles (outer membrane fragments) seen in fig 4 have a diameter of about $120 \mathrm{~nm}$.

The bacteria are loosely attached to the cotton fibre (fig 2), and in the negatively stained preparation no pili or other projections able to participate in the attachment process were visible.

\section{Discussion}

Electron microscopy shows the bacteria of this cotton sample to be flagellated Gram-negatives, as shown by their cell wall structure. The large amounts of free and liberating endotoxin may be clearly seen both in negatively stained and thin-sectioned material. Although this experiment cannot be considered to represent natural conditions, it indicates that endotoxins may be secreted into the environment by the Gram-negative cotton bacteria. The biological activity and the inhalation toxicity of endotoxin is not dependent on whether the endotoxin is free or bound to a living bacterium. ${ }^{8}$

The close association between the bacteria and the cotton fibre was also shown. No pili were found in this experiment, and the attachment of the bacteria to the fibre seems to be loose. This is consistent with the view that the cotton bacteria are easily detached from the fibres and thus produce a heavy microbial contamination into the air of cotton mills. ${ }^{12}$

Several investigators have suggested that the endotoxins of Gram-negative bacteria on cotton participate in the induction and the development of byssinosis. Determined by the Limulus lysate assay ${ }^{9}$ airborne endotoxins have been present in cardrooms in concentrations of 0.2 to $1.6 \mu \mathrm{g}$ per cubic metre. ${ }^{10} 11$ Studies on cotton mill workers have shown that a relation exists, either in terms of subjective symptoms or change in respiratory function, between exposures to Gram-negative bacteria and to endotoxins and the prevalence of byssinosis. ${ }^{212} 13$ The purified endotoxins of typical cotton bacteria increase the number

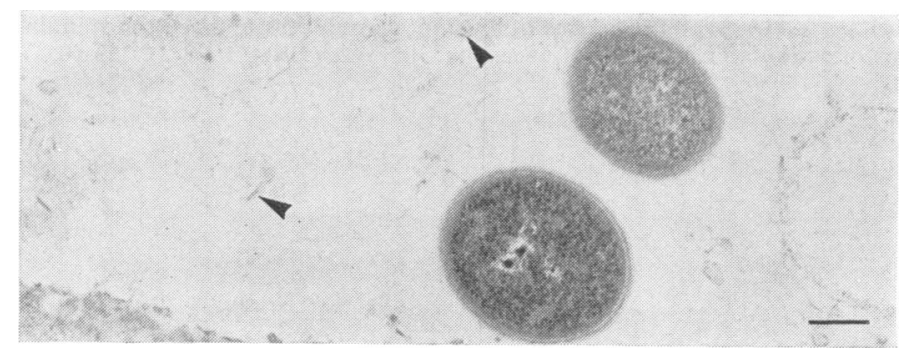

Fig 3 Thin sectioned bacteria and endotoxin (arrowheads) around them. Bar, $0 \cdot 2 \mu \mathrm{m}$. 


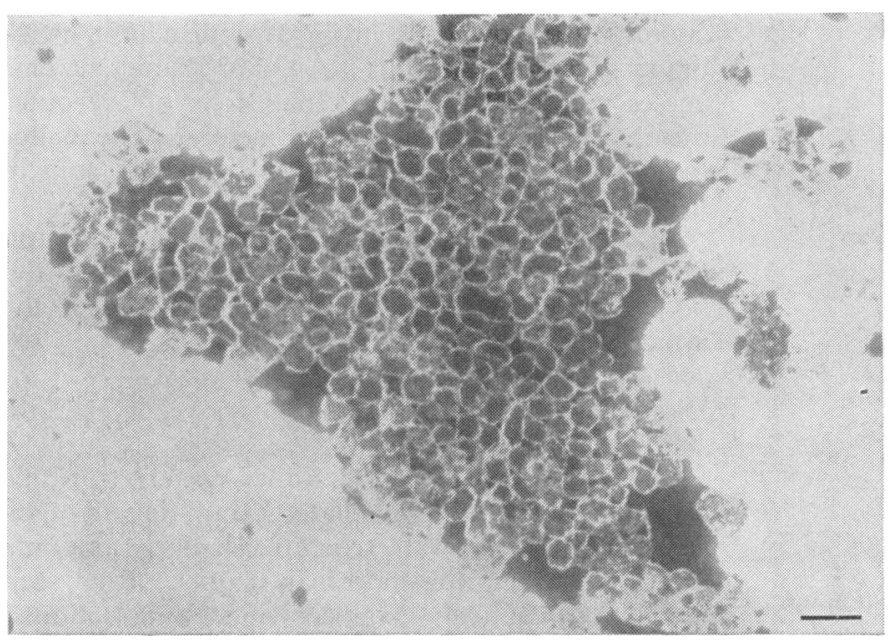

Fig 4 Negatively stained endotoxin (outer membrane fragments). Bar, $0 \cdot 2$ $\mu m$.

of macrophages and polymorphonuclear leucocytes in the airways of experimental animals (guinea-pigs) after inhalation. ${ }^{8} \mathrm{~A}$ similar response has been found in guinea-pigs that have inhaled aerosols of cotton dust or bract extracts ${ }^{6}$ or an aerosol containing cells of pure-cultured Gram-negative cotton bacteria. ${ }^{1}$ This experimental animal model is currently applied for the evaluation of the role of endotoxins in byssinosis and other respiratory disorders such as humidifier fever.

This work was partly (IH) funded by grants from Cotton Incorporated through the Department of Environmental Hygiene, University of Gothenburg, Gothenburg, Sweden. We thank Ms Tuire Koro for skilled technical help.

\section{References}

1 Rylander R, Lundholm M. Bacterial contamination of cotton and cotton dust and effects on the lung. $B r J$ Ind Med 1978;35:204-7.

${ }^{2}$ Haglind P, Lundholm M, Rylander R. Byssinosis prevalence in Swedish cotton mills. Br J Ind Med 1981;38: 138-43.

${ }^{3}$ Andersen BM, Skjorten F, Solberg O. Electron microscopical study of Neisseria meningitidis releasing various amounts of free endotoxin. Acta Pathol Microbiol Scand (B) 1979;87:109-15.

${ }^{4}$ Bradley SG. Cellular and molecular mechanisms of action of bacterial endotoxins. Ann Rev Microbiol 1979;33: 67-94.

${ }^{5}$ Galanos C, Lüderitz $O$, Rietschel ET, Westphal $O$. Newer aspects of the chemistry and biology of bacterial lipopolysaccharides, with special reference to their lipid A component. In: Goodwin TW, ed. International review of biochemistry, biochemistry of lipids II. Vol 14. Baltimore: University Park Press, 1977:239-335.

${ }^{6}$ Rylander R, Snella M-C. Acute inhalation toxicity of cotton plant dusts. Br J Ind Med 1976;33:175-80.

${ }^{7}$ Anderson TF. Techniques for the preservation of threedimensional structure in preparing specimens for the electron microscope. Transactions of the New York Academy of Sciences 1951;13:130-4.

${ }^{8}$ Helander I, Salkinoja-Salonen M, Rylander R. Chemical structure and inhalation toxicity of lipopolysaccharides from bacteria on cotton. Infect Immun 1980;29:859-62.

${ }^{9}$ Wildfeuer A, Neymer B, Schleifer KH, Haferkamp O. Investigations on the specificity of the limulus test for the detection of endotoxin. Appl Microbiol 1974;28:867-71.

${ }^{10}$ Fischer JJ. The microbial composition of cotton dusts, raw cotton lint samples and the air of carding areas in mills. In: Wakelyn PJ, ed. Proceedings of the third special session on cotton dust research, Beltwide cotton production research conference, Phoenix, Arizona. Memphis: National Cotton Council of America, 1979.

${ }^{11}$ Cinkotai FF, Lockwood MG, Rylander R. Airborne bacteria and the prevalence of byssinosis symptoms in cotton mills. Am Ind Hyg Ass J 1977;38:554-9.

12 Rylander R, Imbus HR, Suh MW. Bacterial contamination of cotton as an indicator of respiratory effects among card room workers. Br J Ind Med 1979;36:299-304.

${ }^{13}$ Cinkotai FF, Whitaker CJ. Airborne bacteria and the prevalence of byssinotic symptoms in 21 cotton spinning mills in Lancashire. Ann Occup Hyg 1978;21:239-50. 